\title{
Wapiti Formation and
}

\section{1,75}

Trout Peak Trachyandesite

Northwestern Wyoming

By WILLIS H. NELSON and WILLIAM G. PIERCE

CONTRIBUTIONS TO STRATIGRAPHY

GEOLOGICAL SURVEY B ULLETIN 1254-H

Description of two new formations

in the Absaroka Mountains, Wyoming 


\section{UNITED STATES DEPARTMENT OF THE INTERIOR}

STEWART L. UDALL, Secretary

GEOLOGIGAL SURVEY

William T. Pecora, Director

U.S. GOVERNMENT PRINTING OFFICE

WASHINGTON : 1968

For sale by the Superintendent of Documents, U.S. Government Printing Office Washington, D.C. 20402 - Price 10 cents (paper cover) 


\section{CONTENTS}

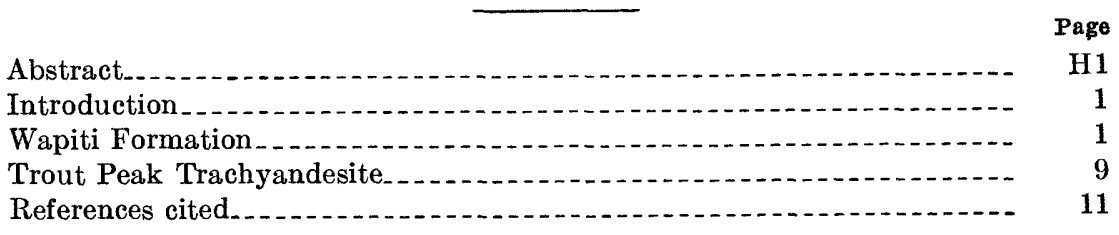

\section{ILLUSTRATIONS}

FIGURE 1. Map showing generalized distribution of the Wapiti Formation and the Trout Peak Trachyandesite in the northeastern Absaroka Mountains, northwestern Wyoming.-..--

2. Generalized stratigraphic sections.

Page

\section{TABLE}

TABLE 1. Chemical and normative analyses of rocks of the Wapiti Formation and the Trout Peak Trachyandesite............. 

CONTRIBUTIONS TO STRATIGRAPHY

\title{
WAPITI FORMATION AND TROUT PEAK TRACHYANDESITE, NORTHWESTERN WYOMING
}

\author{
By Willis H. Netson and Winliam G. Pierce
}

\begin{abstract}
The volcanic rocks of the northeastern Absaroka Mountains consist of lava flows that are interbedded with breccia, sandstone, siltstone, and conglomerate composed, wholly or in part, of volcanic detritus. The name Wapiti Formation is given to the lower 1,500 to 4,000 feet of this heterogeneous assemblage, excluding the Cathedral Cliffs Formation, which locally underlies the Wapiti Formation in the northwestern part of the area. Over part of its extent the formation includes, near the middle, as much as 1,100 feet of lava flows herein called the Jim Mountain Member.

A sequence of lava flows 150 to 1,000 feet thick that overlie the Wapiti Formation is named the Trout Peak Trachyandesite.

The Wapiti Formation is of early or middle Eocene age, or both. The Trout Peak Trachyandesite is considered to be of Eocene (probably late Eocene) age, although potassium-argon dates conflict with this age assignment.
\end{abstract}

\section{INTRODUCTION}

The names Wapiti Formation and Trout Peak Trachyandesite are introduced for slightly deformed rocks of Eocene age that were heretofore informally called early basic breccia and early basalt sheets respectively (Hague, 1899). These informal names have been useful in reconnaissance studies that have shown the general distribution of rocks in the volcanic pile that makes up much of the northern Absaroka Mountains. The names are not suitable for use as formal names, however, because they are not descriptively accurate, they are not geographically derived, and they are not consistently used.

\section{WAPITI FORMATION}

The Wapiti Formation is here named from exposures between about 6,800 and 10,300 feet altitude in the mountains north and south of the Wapiti Post Office located about 18 miles west of Cody, Wyo. Stratigraphic section $C$ north of the Wapiti Post Office is designated the type section (figs. 1 and 2 ). 


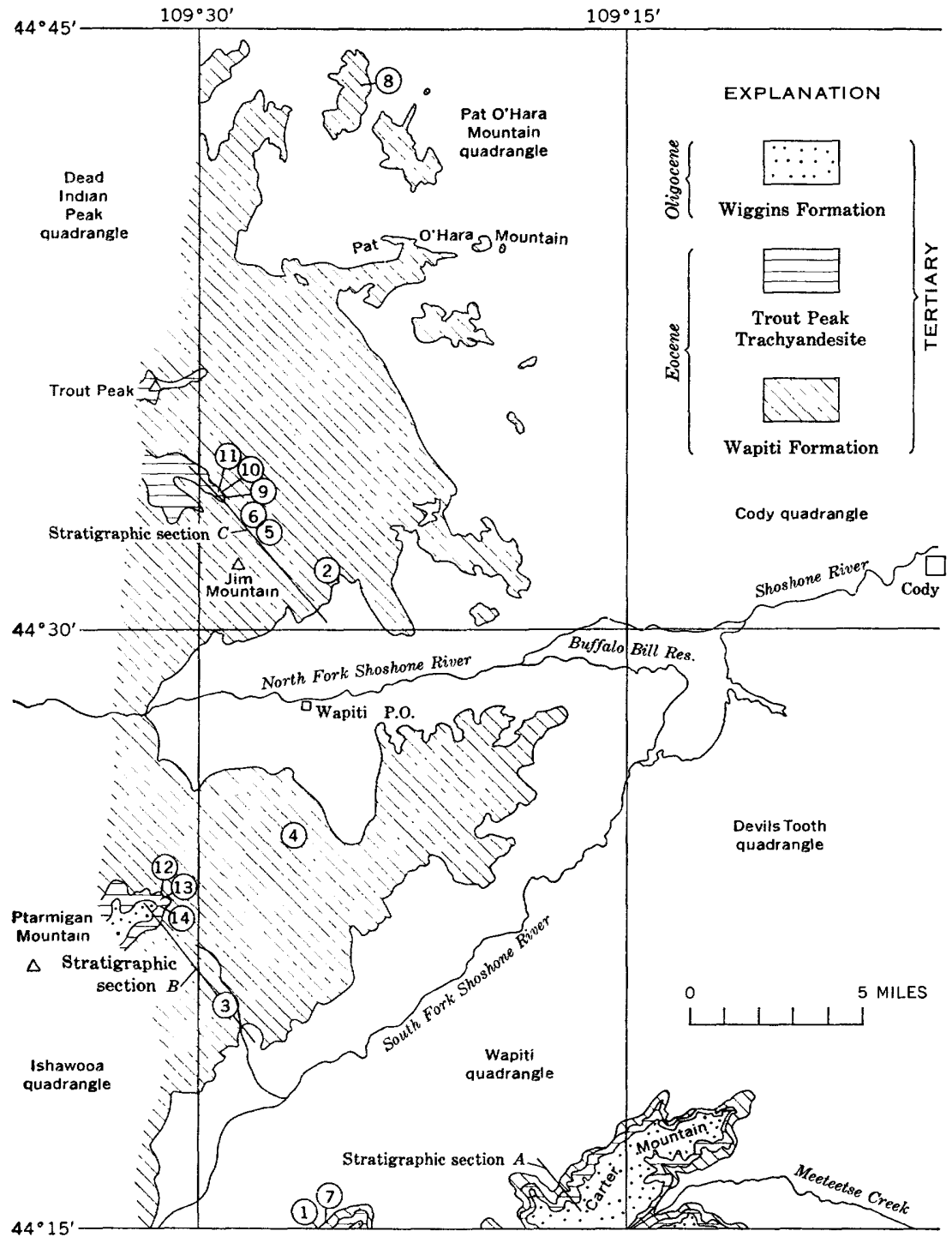

Frgure 1.-Generalized distribution of the Wapiti Formation and the Trout Peak Trachyandesite in the northeastern Absaroka Mountains, northwestern Wyoming. Circled numbers show the locations of the analyzed specimens in table 1. Stratigraphic sections $A, B$, and $C$ are shown in figure 2. 
The Wapiti Formation is composed of volcanic breccia, standstone, siltstone, conglomerate, and lava flows. The relative abundance of these rock types varies both vertically and horizontally (fig. 2). Individual layers that range from a few feet to a few hundreds of feet in thickness are dominated by one rock type and interfinger and are interbedded with layers dominated by other rock types.

The volcanic breccia is somber shades of brown, reddish brown, gray, and rarely greenish gray. Most of the breccia occurs as lenticular masses a few to many tens of feet in thickness and many hundreds of feet in lateral extent. Most of the thicker masses of breccia consist of numerous irregular beds, but some of them seem to be a single thick bed. Most of the breccia is believed to have been deposited as mudflows, as indicated by poor sorting, and each bed of such breccia seems to represent a single mudflow. Better sorting in some of the beds of breccia suggests that those beds were deposited by streams. Other beds have intermediate textural characteristics which suggest that there was virtually a complete transition between very fluid water-rich mudflows and fluvial transport and deposition. Most of the material comprising the breccia is volcanic detritus, either pyroclastic material or material derived from fragmentation of preexisting solid volcanic rocks. The matrix of the breccia is fine grained and is composed dominantly of silt to coarse-sand-sized detritus. It contains larger fragments that range from coarse-sand size to several feet across, but which are commonly from 1 to 12 inches across. The size of these larger fragments varies from bed to bed and also laterally within a given bed.

The individual fragments in the breccia are fine-grained volcanic rocks that contain phenocrysts of plagioclase, pyroxene, and local olirine or hornblende. Many of the fragments are vesicular. An analysis of a specimen of breccia that seems to be typical of the darkcolored breccia (table 1, specimen 1) suggests that the breccia is trachyandesite and similar to most of the flows in the formation.

A small proportion of the breccia in the formation is rich in hornblende and has a light-colored matrix. Both features suggest that this breccia is somewhat more felsic than the more abundant, darker breccia described above. This is also indicated by a chemical analysis of a specimen of light-colored breccia (table 1, specimen 2), which indicates a dacitic composition. The texture of the detritus in the light-colored breccia suggests that most of it is pyroclastic; most of the deposits of light-colored breccia seem to have been reworked but some seem to be unmodified aerial deposits.

Volcanic sandstone and siltstone, along with lesser amounts of volcanic conglomerate, commonly occur together in sequences that range from a few feet to many tens of feet in thickness. Most of these rocks 
岁

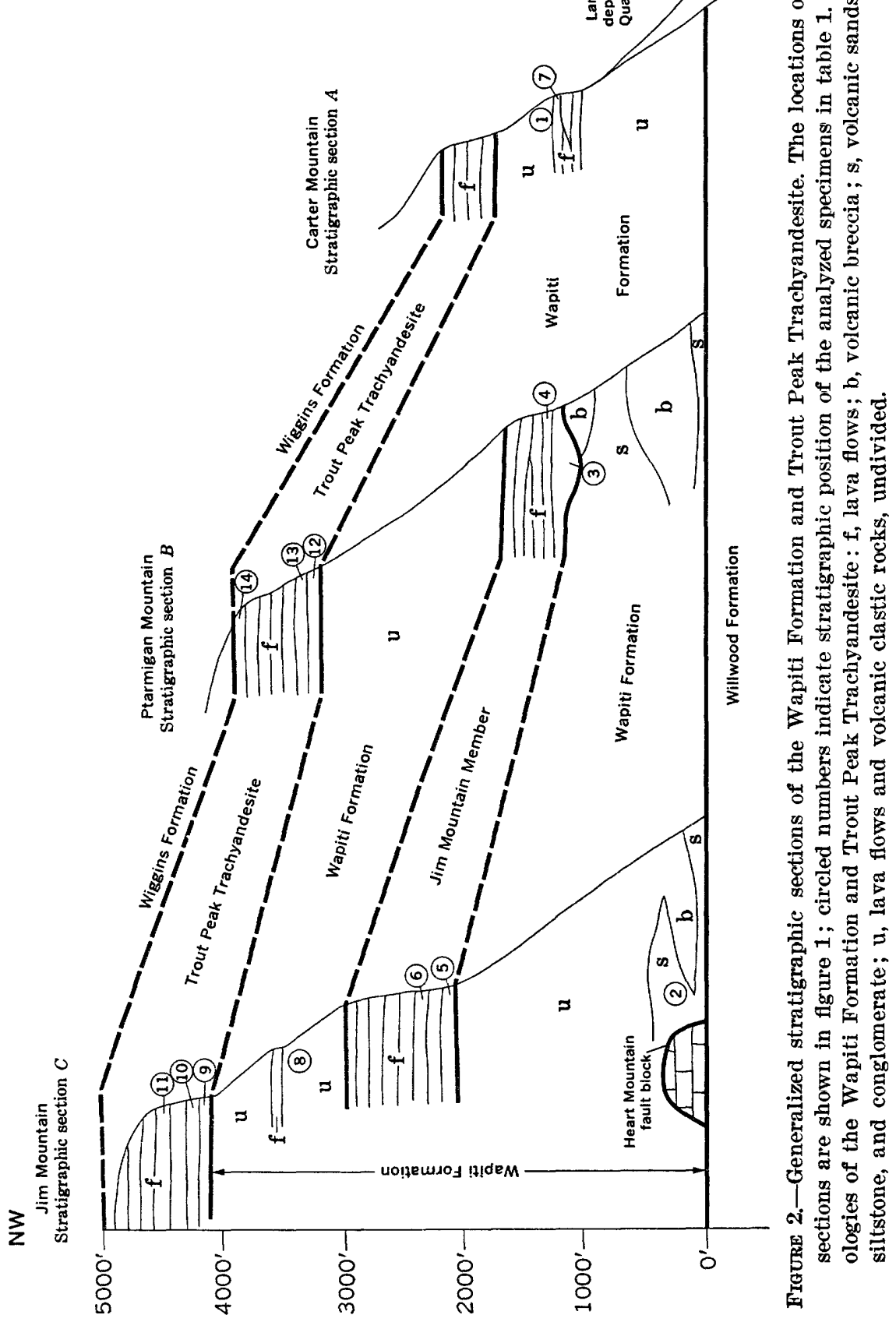



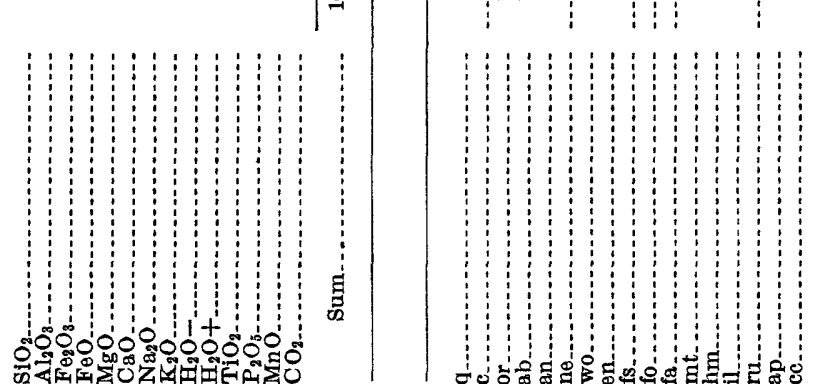
are well bedded and locally crossbedded which suggests that they are stream deposits. A few of the beds of sand-and silt-sized material are so thin, widespread, and poorly sorted that they are thought to be aerially deposited tuffs. The volcanic sandstone, siltstone, and conglomerate consist of medium-brown and gray volcanic detritus including pyroclastic material, fragments of lava flows, detritus derived from volcanic breccia deposits, and quartz and quartzite. Quartzite pebbles and cobbles abound in some of the conglomerate, and petrified wood is sparsely scattered through all the rocks. Some beds are lighter colored and probably somewhat more felsic than the dark-colored rocks just described.

Lava flows, either singly or in sequences of several flows, occur sporadically within the Wapiti Formation. Trachyandesite flows are the most abundant, and dacitic flows, much less so.

The trachyandesite flows within the Wapiti Formation are identical to those of the Trout Peak Trachyandesite, and the description of the flows in the Trout Peak Trachyandesite, which is given below, is applicable to them. These flows commonly are less than 120 feet thick except where they fill channels. Along the creek near section $B$ one of these channel fills is about 400 feet thick; this is illustrated diagrammatically in section $B$, figure 2 .

The name Jim Mountain Member is here given to the prominent sequence of trachyandesite lava flows that occur near the middle of the Wapiti Formation throughout the map area (fig. 1) north of the South Fork of the Shoshone River. Its type section is designated as stratigraphic section $C$ in the vicinity of Jim Mountain (fig. 2). This member consists of a maximum of 8 to 10 flows in the central part of the area; it thins southward, so that in the area between the forks of the Shoshone River, locally only one flow is present at this horizon. As many as three superimposed trachyandesite flows occur within the Wapiti Formation on the north slope of Carter Mountain, but none of them can be confidently correlated across the South Fork valley with the Jim Mountain Member. Specimens 3 through 6, table 1, are of flows from the Jim Mountain Member.

Dacitic lava flows occur mainly in the upper part of the Wapiti Formation. They generally seem to be thinner and less extensive than individual trachyandesite flows, but this may be an illusion that results from the fact that the dacitic flows do not crop out as prominently as the trachyandesite flows. In addition to the plagioclase and pyroxene phenocrysts that occur in the trachyandesite flows, the dacitic flows all contain abundant black acicular amphibole phenocrysts. Specimen 8 , table 1 , is from a dacitic flow. 
Roughly the lower 800 feet of the Wapiti Formation in stratigraphic section $C$, the type section, consists of well-bedded light-colored volcanic sandstone, siltstone, and conglomerate that enclose wedge- or lenticular-shaped masses of irregularly bedded somber-colored volcanic breccia. These masses are as much as 400 feet thick and occur discontinuously at the base of the formation. The next higher part of the formation consists of about 1,000 feet of somber-colored breccia in irregular beds that range from a few feet to several tens of feet in thickness and that grade into and are interbedded with volcanic sandstone. Above this are eight trachyandesite flows totaling about 1,000 feet thick which comprise the Jim Mountain Member of the Wapiti Formation. The upper 1,000 feet of the Wapiti Formation above the Jim Mountain Member consists of interbedded volcanic breccia, sandstone, siltstone, and discontinuous lava flows. Somber-colored breccia is the predominant rock; light-colored breccia, in layers up to a few tens of feet in thickness, is sporadically distributed throughout the upper 1,000 feet of the formation. The somber- and light-colored volcanic sandstone and siltstone and trachyandesite and dacite lava flows are interbedded with the breccia.

Away from the type section, only the Jim Mountain Member and the sandstone and siltstone at the base of the formation can be recognized. Light-colored volcanic sandstone and siltstone form a discontinuous but widespread unit at the base of the formation. This unit is commonly only a few feet to a few tens of feet thick, but locally it is much thicker; for example, on Pat O'Hara Mountain it is more than 300 feet thick, and near stratigraphic section $B$ all the volcanic breccia beneath the Jim Mountain Member locally pinches out at the same place, so that the entire formation beneath the Jim Mountain Member locally consists of volcanic sandstone, siltstone, and conglomerate. In the type section, as already noted, volcanic sandstone, siltstone, and conglomerate locally make up the entire lower 800 feet of the formation.

The distribution of rock types within the Wapiti Formation varies from the distribution of rock types at the type locality, and although most of the variations are erratic, the overall thickness of the formation, the thickness of the Jim Mountain Member, and the proportion of breccia in the formation all decrease, somewhat systematically, from north to south. The overall thickness of the formation ranges from at least 3,800 feet in the northern part of the area to about 1,700 feet at the southern edge; this is shown diagrammatically in figure 2. The Jim Mountain Member, which is about 1,000 feet thick in the northern part of the area, is thinner and may be locally absent in the southern part. In the northern part volcanic sandstone and silt- 
stone occur only as thin wedges and lenses interbedded in volcanic breccia, but in the southern part the relationships are reversed-breccia occurs as wedges and lenses within volcanic sandstone, siltstone, and associated conglomerate.

The three trends that have just been noted suggest that much of the material in the Wapiti Formation came from a volcanic source or sources in or near the northwestern part of the area of figure 1. However, no volcanic centers have been identified within this area, and although several are known to the northwest, none of these have as yet been identified specifically as a source of material in the Wapiti Formation.

The Wapiti Formation is in part stratigraphically equivalent to the middle Eocene Pitchfork Formation which Hay (1956) proposed for a sequence of volcanic sandstone and siltstone in the area south of figure 1. The Pitchfork Formation is a facies of the sequence of volcanic rocks that Hague (1899) had informally termed "early basic breccia." Hay noted that the volcanic sandstone and siltstone, which he called the detrital facies, interfingered with breccia, and he assigned the detrital tongues to the Pitchfork Formation and continued to use the term early basic breccia for the breccia beds. Thus, the Pitchfork Formation was set up to distinguish the part of the sequence composed predominantly of volcanic sandstone and siltstone from the brecciarich part of the sequence. If the Pitchfork Formation were extended to include the rocks here defined as the Wapiti Formation, this distinetion would be obliterated, an extensive revision of the description of the rocks composing the Pitchfork Formation would be required, and it would defeat the purpose for which the Pitchfork was named. Therefore, we believe that the name Pitchfork Formation should be restricted to the breccia-poor sequence of rocks in the area south of figure 1 , and that it is useful to introduce the new name Wapiti Formation for the breccia-rich sequence of rocks in the area of figure 1. Thus, the usage of Pitchfork, as originally proposed and as used up to the present time, remains unchanged. Because of inadequate exposures, it is impossible to map the details of the transition between these two formations. Instead the mutual boundary is arbitrarily defined as the place that separates areas wherein breccia is the dominant rock type from areas wherein it is the subordinate rock type. This change occurs within a fairly narrow zone near, and approximately parallel to, the southern boundary of figure 1 .

The Wapiti Formation in much of the area shown in figure 1 overlies the Willwood Formation of early Eocene age and in a lesser area overlies older rocks, with slight to locally strong discordance. Also, in a number of places the Wapiti Formation surrounds and buries blocks 
of Paleozoic rock, mostly carbonate, some of them hundreds of feet thick and thousands of feet across. These blocks were dispersed on the early Eocene land surface by the Heart Mountain detachment fault before deposition of the Wapiti Formation (Pierce, 1957, 1963). During the deposition of the lower part of the Wapiti Formation, these blocks were topographic highs, which shed fragments up to many feet across that became sparsely distributed in the lower part of the formation. In the north-central part of the Wapiti quadrangle, and locally elsewhere, blocks of bedded sedimentary rocks of both the Willwood and Wapiti Formations have been incorporated in the lower 500 feet of the Wapiti Formation, probably by small-scale gliding tectonics. Many of these blocks are steeply and randomly tilted. In the northwestern corner of the Pat O'Hara Mountain quadrangle, the Wapiti Formation locally overlies light-colored tuff, volcanic sandstone, siltstone, and breccia of the Cathedral Cliffs Formation, of late early or early middle Eocene age (Pierce, 1963). These rocks are discordant beneath the Wapiti Formation and lie on Heart Mountain detachment blocks on which they seem to have been deposited before the Heart Mountain faulting.

As noted above, the Wapiti Formation correlates in part with the Pitchfork Formation. Vertebrate remains of middle or late Eocene age were collected by Jepsen (1939) and Van Houten (1944) from the lower part of the Pitchfork Formation. Jepsen restudied these two collections and he reported (in Hay, 1956, p. 1883-1884) that three of the species "all indicate early Bridgerian age" and one "suggests late Wasatchian (Wind River)." Dorf (1939) reports that the flora near Valley, Wyo. (which is from the Wapiti Formation of this report) is of late Green River to early Bridger age, which he considers early middle Eocene. From the Wapiti Formation within or near the Wapiti quadrangle, fossil plant collections identified by R. W. Brown and Jack A. Wolfe and reported in Pierce (1963) indicate a probable middle Eocene age for four collections, and a late early or early middle Eocene for one collection. Thus, the Wapiti Formation is assigned an age of early or middle Eocene or both.

\section{TROUT PEAK TRACHYANDESTTE}

The Trout Peak Trachyandesite is here named from exposures on Trout Peak (fig. 1) about 10 miles northwest of Wapiti Post Office. The type section extends from the top of Trout Peak at an altitude of 12,244 feet down to about 11,400 feet. Figure 1 shows the distribution of the formation in the area that we have studied.

The Trout Peak Trachyandesite consists of lava flows locally interbedded with subordinate amounts of volcanic clastic rock. The flows are gray and weather brown and reddish brown; they commonly have 
a maximum thickness of about 150 feet and are locally columnar jointed. The tops and bottoms of the flows are commonly vesicular and brecciated owing to flowage of the central parts after the outer parts had solidified. They have aphanitic groundmasses which contain plagioclase and pyroxene, and locally olivine or hornblende phenocrysts. Analyses 9 through 14, table 1, are of specimens of these flows, and show them to be trachyandesite.

Five lava flows, each slightly more than 100 feet thick, cap the upper part of Trout Peak; the lowest flow is separated from the overlying flows by about 150 feet of light-colored, moderately well-bedded volcanic sandstone and siltstone. Nine flows cap the ridge about halfway between Trout Peak and the northwest corner of the Wapiti quadrangle. Flows of the Trout Peak Trachyandesite occur on a northeast-trending spur of Ptarmigan Mountain (fig. 1). There the formation is about 1,000 feet thick and consists of 9 or 10 flows of which the second and third from the base are separated by about 150 feet of orange lapilli tuff.

The continuity of the Trout Peak Trachyandesite in the area of figure 1 is interrupted by the valleys of both the North and South Forks of Shoshone River. Correlation across these valleys is suggested first by the similarity of the flows that make up this formation throughout the area. This is not conclusive, however, because similar flows also occur at various levels in the underlying Wapiti Formation. Correlation across the North Fork is based with considerable confidence on the continuity of similar sequences of rocks within the Wapiti Formation, especially the Jim Mountain Member, on the two sides of the valley. Correlation across the South Fork valley is supported by the fact that the Trout Peak Trachyandesite flows are overlain by light-colored rocks of the Wiggins Formation on Carter and Ptarmigan Mountains. Correlation across both the North and South Forks of the Shoshone River is further confirmed by the widespread occurrence of the Trout Peak Trachyandesite at about the same altitude for several miles west of the mapped area (fig. 1).

In the area of figure 1 the contacts between the Trout Peak Trachyandesite and the Wapiti Formation below and the Wiggins Formamation above seem to be conformable and gradational. The lower part of the Wiggins Formation consists of light-colored tuffaceous sandstone, siltstone, conglomerate, and breccia that are similar to material that occurs between some of the Trout Peak Trachyandesite flows and also locally within the upper part of the Wapiti Formation.

The Trout Peak Trachyandesite lies between the Wapiti Formation, which may be as young as middle Eocene, and the Wiggins Formation, which Love $(1939$, p. 83$)$ considered to be Oligocene in age based on 
vertebrate fossils from about 40 miles south of the area of figure 1 . Wilson (1963, p. 19) reported that volcanic ash near the base of the Wiggins Formation on the south side of Carter Mountain has provided a potassium-argon date that indicates, "an early Oligocene agepossibly latest Eocene (R. S. Houston, oral commun., 1962)," whereas vertebrate fossils from immediately below the ash "suggest an Eocene age (E. L. Simons, oral commun., 1962)," J. D. Love (oral commun., $1965)$ believes that the rocks containing the vertebrate fossils are distinctly different from most of the rocks of the Wiggins Formation, and he has suggested that there may be an unconformity between the rocks that contain the vertebrate fossils and the Wiggins Formation. H. L. Prostka (written commun., May 23, 1967) has collected samples both from a welded tuff and from a dike. The tuff is interbedded with, and the dike cuts, rocks that are probably equiralent to the Trout Peak Thachyandesite about 20 miles west of the map area (fig. 1) J. D. Obradovich, U.S. Geological survey, has obtained potassium-argon dates of 51.3 and $52.6 \pm 1.6 \mathrm{~m}$.y. from these samples. These dates are too old to be reconciled with the possible middle Eocene age indicated by fossils for part of the underlying Wapiti Formation; we therefore consider the Trout Peak Trachyandesite to be late Eocene age, at least until further data are available.

\section{REFERENCES CITED}

Dorf, Erling, 1939, Middle Eocene flora from the volcanic rocks of the Absaroka Range, Park County, Wyoming [abs.] : Geol. Soc. America Bull., v. 50, no. 12 , pt. 2, p. 1906-1907.

Hague, Arnold, 1899, Description of the Absaroka quadrangle (Crandall and Ishawooa quadrangles) [Wyoming]: U.S. Geol. Survey Geol. Atlas, Folio $52,6 \mathrm{p}$.

Hay, R. L., 1956, Pitchfork Formation, detrital facies of early basic breccia, Absaroka Range, Wyoming: Am. Assoc. Petroleum Geologists Bull., v. 40, no. 8, p. 1863-1898.

Jepson, G. L., 1939, Dating Absaroka volcanic rocks by vertebrate fossils [abs.] : Geol. Soc. America Bull., v. 50, no. 12, pt. 2, p. 1914.

Love, J. D., 1939, Geology along the southern margin of the Absaroka Range, Wyoming: Geol. Soc. America Spec. Paper 20, $134 \mathrm{p}$.

Pierce, W. G., 1957, Heart Mountain and South Fork detachment thrusts of Wyoming: Am. Assoc. Petroleum Geologists Bull., v. 41, no. 4, p. 591-626.

1963, Cathedral Cliffs Formation, the early acid breccia unit of northwestern Wyoming: Geol. Soc. America Bull., v. 74, no. 1, p. 9-22.

Shapiro, Leonard, and Brannock, W. W., 1962, Rapid analysis of silicate, carbonate, and phosphate rocks: U.S. Geol. Survey Bull. 1141-A, 56 p.

Van Houten, F. B., 1944, Stratigraphy of the Willwood and Tatman Formations in northwestern Wyoming: Geol. Soc. America Bull., v. 55, no. 2, p. 165-210.

Wilson, W. H., 1963, Correlation of voleanic rock units in the southern Absaroka Mountains, northwest Wyoming: Wyoming Univ., [Laramie] Contr. Geology, v. 2, p. 13-20. 
